\title{
GEOGRAPHICAL CONSIDERATIONS REGARDING THE TOURIST DESTINATION PĂDUREA CRAIULUI MOUNTAINS
}

\author{
Grigore Vasile HERMAN* \\ University of Oradea, Department of Geography, Tourism and Territorial Planning, 1 University St., Oradea 410087, \\ Romania, e-mail: grigoreherman@yahoo.com
}

\section{Varodi Mihaela OLĂU}

Ph.D. candidate, University of Oradea, Faculty of Geography, Tourism and Sport 1 University Street, Oradea, 410087, Romania, e-mail: oradeanu_miha@yahoo.com

\section{Vasile GRAMA}

University of Oradea, Department of Geography, Tourism and Territorial Planning, 1 University St., Oradea 410087, Romania, e-mail: vasile.grama2014@gmail.com

\section{Cezar MORAR}

University of Oradea, Department of Geography, Tourism and Territorial Planning, 1 University St., Oradea 410087, Romania, e-mail: cezarmorar@yahoo.com

Citation: Herman, G.V., Varodi, M.O., Grama, V., Morar, C. (2019). Geographical Considerations Regarding the Tourist Destination Pădurea Craiului Mountains. Analele Universitătii din Oradea, Seria Geografie, 29(1), 102-108. https://doi.org/10.30892/auog.291111-808

\begin{abstract}
The affirmation and development of local and regional tourism as a reflection of the technological advances imposed by globalization have led to a certain specialization of the spatial entities in the direction of shaping and asserting the tourist destinations. On this background, the present study aims to underline some geographic aspects that contribute to highlighting structural and functional aspects of the tourist destination Pădurea Craiului. In this respect, the transport infrastructure, tourism infrastructure, tourist services and tourism resources were analyzed, the results being transposed in textual and cartographic format.
\end{abstract}

Key words: Pădurea Craiului Mountains, tourism destination, tourism resources

$* \quad * \quad * \quad * \quad * \quad *$

\section{INTRODUCTION}

The tourist destinations are structurally and functionally well-defined spatial entities, with roles and functions in attracting and retaining potential tourists for a certain period of time. At national and international level, the analyse and study of tourist destinations is increasingly necessary in the last period of time, due to the increasing role and importance of tourism in the 
development of local economies (Herman et al., 2017, 2018; Ilieș et al., 2010; Ilie et al., 2017) and in the conservation and economic valorization of protected natural areas (Herman et al., 2016a, 2016b; Ilieș et al., 2015, 2017a, 2017b; Siikamäki et al., 2015; Tătar et al., 2017; Tolvanen and Kangas, 2016; Wendt et al., 2019). Considering the fact that the Pădurea Craiului Mountains overlap over such protected areas, the concerns are raising, regarding the tourism in general and the development of the tourist activities in particular, knowing that the anthropic activity can have both positive and negative effects on the term short, medium and long term (Ballantyne and Pickering, 2013; Herman, 2009; Morar, 2011; Morar, 2012a; Rankin et al., 2015).

From the analysis of the specialized literature and the daily practice it was found that in the emergence, the evolution and the dynamics of the tourist destinations, an important role is played by a number of determinant factors among which we mention the transport infrastructure (Matoga and Pawłowska, 2018; Rosik et al., 2018, Więckowski et al., 2014), the tourist infrastructure (Kapera, 2018, Herman and Wendt, 2011), the tourist resources (Gaceu and Herman, 2010; Gaceu et al., 2018; Lindner-Cendrowska, 2013), the tourist perception (Bar et al., 2016; Toral et al., 2018), the competitiveness of tourist destinations (Mendola and Volo, 2017; Sainaghi et al., 2017; Gómez-Vega and Picazo-Tadeo, 2019), the structural and functional evolution of destinations (Herman and Tătar, 2015; Mariani, 2014) and by the funding opportunities (Morar, 2012b).

The present paper aims at studying the area of the Pădurea Craiului Mountains in order to analyze the attributes necessary for its nomination as a tourist destination.

The Pădurea Craiului Mountains, with an area of $1150 \mathrm{~km}^{2}$, represent a fourth-order geographic unit, administratively framed by the county of Bihor, occupying the tenth part of its territory (Geography of Romania, I, 1983). The mountains descend to the North-West of the Bihor-Vlădeasa Mountains, forming along with the Codru-Moma, Plopiș, Meseș and Zarand Mountains, the so called Apuseni Peninsula (Rusu 1988), framed by Crişul Repede to the north and by Crişul Negru to the south (Figure 1).

The neighboring geographic units of the same order are the Vad-Borod Depression in the North-West, the Bihor-Vlădeasa Mountains in the East, the Beiuş Depression in the South and the Cordăului, Tășadului and Holodului Hills at the Southwest (Novac, 2006).

The Pădurea Craiului Mountains are distinguished by the massive unitary layout suspended above the surrounding relief units, aspect due to the basic level of the two neighboring depressions, Vad and Beiuş. The mountain unit is an intensely fragmented platform, in a series of isolated peaks and massifs, such as hillock and cornets, where the positive forms alternate with the negative ones, the depth of fragmentation being between 150-250 $\mathrm{m}$ in the Northwest and 300-600 $\mathrm{m}$ in South-West (Geography of Romania, III, 1987).

The altitudes are generally low, under $1000 \mathrm{~m}$, the highest one occurring in the Eastern part (the peak of Hodrângusa, $1027 \mathrm{~m}$ ). The altitudes are descending westwards to the two depressions, in the north the Vad Depression and in the south the Beiuş Depression.

Depending on the geological substrate, there are two important categories of reliefs in the Pădurea Craiului Mountains, those specific to the impermeable rocks and those specific to the limestone.

The relief developed on impermeable rocks is represented, according to the age and nature of the rocks, by high, massive shapes and by forms of relief with low altitude, in some cases they are flat, in others their personality is lacking (Rusu, 1988).

The relief developed on the karst is very varied, complex and spectacular, being represented by the whole range of exo and endokarst, generated not only by the lithology and structure, but also to special paleo-climatic conditions and by the position of the unit, in relation to the erosion base. The karst of the Pădurea Craiului Mountains is represented by all specific forms, approaching the unit to holokarst (Rusu, 1988).

Since the competitiveness and the evolution of the tourist destinations are related to the established destinations, the analysis of the transport infrastructure, the tourist infrastructure, the tourist services and the tourism resources that define the tourist destination Pădurea Craiului must be performed. 


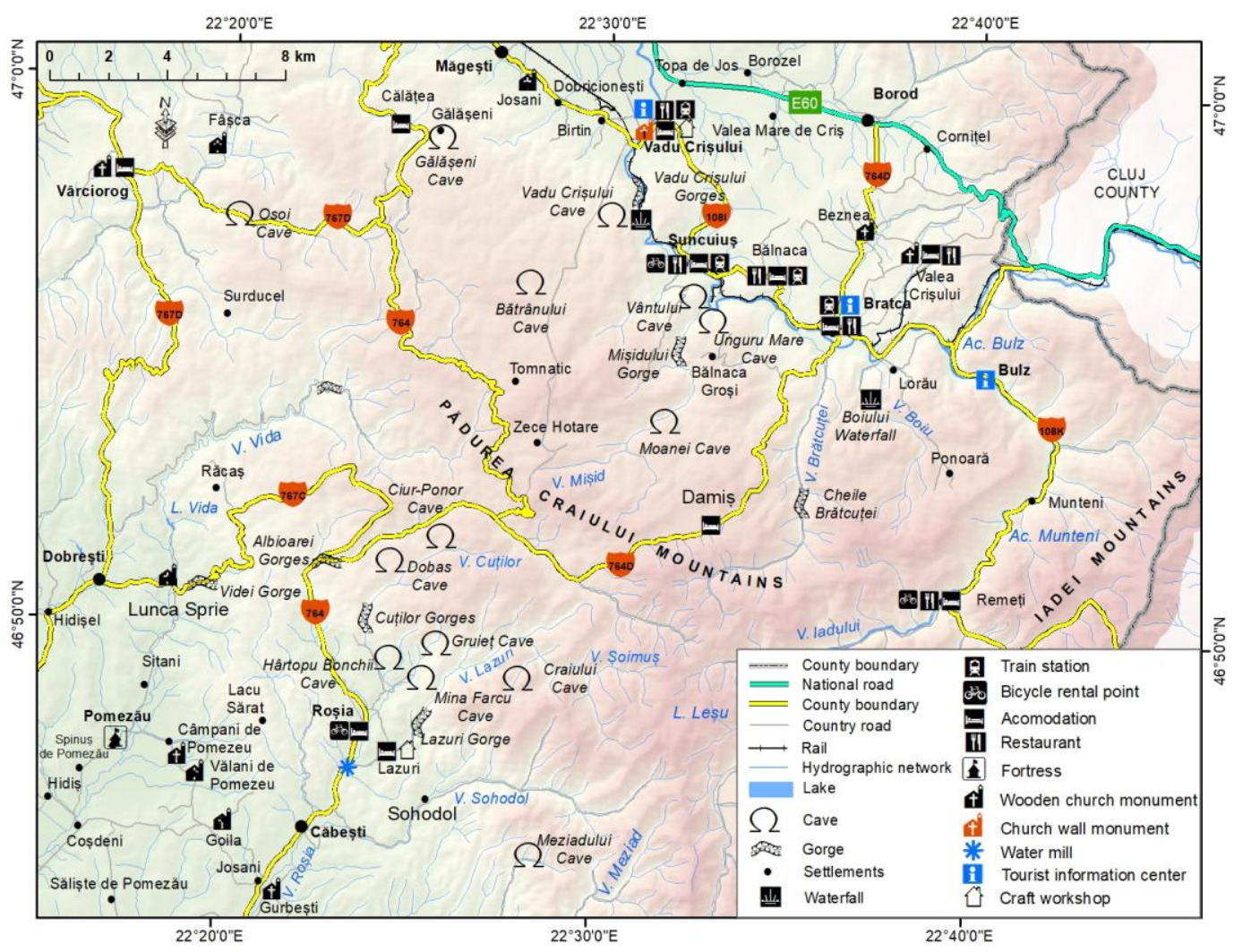

Figure 1. Synthetic map of the Tourist Destination Pădurea Craiului Mountains

\section{THE RESEARCH METODOLOGY}

The elaboration of the present study involved the spatial and relational analysis of several elements necessary for shaping the tourist destinations (transport infrastructure, tourism infrastructure, tourism services and tourism resources). The data necessary for carrying out the study, obtained from the Ministry of Tourism, from the literature and from the field work, were analyzed with ArcGis 10.6 in order to understand the spatial relations between the elements defining the tourism destination Pădurea Craiului (Herman, 2010; Ilieş et al. 2014, 2016; Romocea et al., 2018).

The results obtained consist in the creation of a synthetic map of the Pădurea Craiului tourist destination, on which the defining elements that led to the shaping of this destination, respectively of the study "Several geographical considerations regarding the Tourist Destination Pădurea Craiului Mountains" were presented.

\section{THE TRANSPORTATION INFRASTRUCTURE}

Located in the northwest of the Apuseni Mountains, between the Crişul Repede Defile, to the north, and the Depression of Beius to the south, the Pădurea Craiului destination can be accessed both by train and by car. The train access is provided by the railway Oradea-ClujNapoca-Bucharest (with the train station Bratca, Şuncuiuş, Vadu Crişului), while the car access is via the European Road 60, connecting Oradea to Cluj-Napoca, respectively the European Road 79 (Oradea-Beiuş), which continues with the county road 764 (Beiuş-Bratca). 


\section{THE TOURIST INFRASTRUCTURE}

The accommodation structures are representative elements in the shaping of tourist destinations, their appearance and evolution having close links with the tourist potential of the space in which they appear and manifest (Herman and Tătar, 2015). The tourist destination Pădurea Craiului is represented by the existence of a number of 32 accommodation structures, with a capacity of 709 beds. The spatial analysis of the accommodation structures in the studied area highlighted the existence of three major groups, located in the North-East (represented by a number of 14 structures, 357 accommodation beds), in the South-West (represented by 9 accommodation bases, 195 beds) and West, in Remeţi, on the Iad valley (represented by 8 structures, 145 beds). An exception to this rule is the Tourist Pension Mihaiu Sasului from Vârciorog (12 beds) (LSPTC, 2018). It should be underlined that the location of the accommodation structures is closely related to access routes, on the one hand and to the existence of tourist resources, on the other hand.

The food service operators are also representative elements in shaping the tourist destinations, complementing the accommodation structures to meet the primary needs, in connection with gastronomy and recreation. In the studied area there are nine food services operators (1270 seats), located in the North-West of Pădurea Craiului, in Vadu Crisului, Şuncuiuş, Bratca, Valea Crişului and West, in Remeţi (LSPTAP, 2018). For the location of the food service operators, it can be observed the connections with the access routes and with the existence of tourism resources.

Tourist planning elements are structural elements of tourist destinations with important roles and functions in generating tourist motivation.

The first tourist facilities specific to the area under consideration dates back to 1880 when the "the father of the Bihor County tourism", Czaran Gyula, explores the Meziad Cave and undertakes the first tourist planning. Later, in 1903 he proposes and set up the first tourist route from the Pădurea Craiului, between Vadu Crișului and Șuncuiuș. In the same period, the first tourist cottage was built near the Vadu Crișului Cave, the cottage being nowadays abandoned (the Journal of the Pădurii Craiului, 2017).

Currently, the following tourist facilities have to be mentioned: four caves for tourism (respectively, Meziad Cave, Crystal Cave in Farcu mine, Ungurul Mare Cave and Vadu Crişului Cave $)^{1}$, the hiking routes (15 hiking routes, approved and maintained by the Mountain Rescue Service from Bihor County) ${ }^{2}$, the thematic routes (four routes "Discover Roşia Valley", "Forest Stories", "No Trace!", "The Forest Livings") (Bihor Destination Management Agency, 2017, p. 13), the areas and routes for climbing and mountaineering activities (six climbing areas, located in Vadu Crişului, Şuncuiuş, Bulz, Remeţi, Osoi and Lazuri, with a total of 442 routes) ${ }^{3}$ and the viaferrata routes (three routes, the Hodoaba Valley, Zânelor Vertical Slope and Zmăului House).,5 Also, there are five mountain bikes rental centers, located in Suncuiuș (at Extreme Suncuiuș tour operator, near Gradia Pension), Remeţi (at the pensions Apuseni Wild and Gornicului, on the Iad Valley), Remetea (six bikes ) and Roşia (six bikes). ${ }^{6}$

\section{THE TOURIST SERVICES}

Tourist Information and Promotion Services are defining attributions for the Tourist Information and Promotion Centers, representing through the roles and the functions performed, together with the transport and tourism infrastructure, another essential element in the emergence and development of the tourist destinations. The destination Pădurea Craiului is represented by the

\footnotetext{
${ }^{1}$ https://www.padureacraiului.ro/speoturism

${ }^{2}$ http://www.salvamontbihor.ro/page/trasee-turistice

${ }^{3}$ http://alpinismbihor.ro

${ }^{4}$ http://alpinismbihor.ro

${ }^{5}$ http://salvamontbihor.ro/page/via-ferrata-vad

${ }^{6}$ https://padureacraiului.ro/rent-a-bike/
} 
existence of the TIPCs (23\% of the total number of Bihor County centers), located in the NorthEast, in Bratca, Vadu Crişului and Bulz. The role and importance of TIPCs in the studied area, in the shaping and development of the Pădurea Craiului tourist destination, emergences from the researches carried out during the period 01.10.2017 - 20.04.2018 and 01.11.2018 - 30.01.2019, using sociological survey based on questionnaire and from web site analysis. The conclusions of the research show that the Tourist Information Center Vadu Crişului and Bulz have an insignificant role, while the National Tourist Information and Promotion Center Bratca has a minor role. A similar situation has also emerged from the web site analysis.

The tourist services are well coordinated and represented in the Pădurea Craiului destination, by a number of 18 operators and six specialized guides (Bihor Destination Management Agency, 2017, p. 25).

\section{THE TOURIST RESOURCES}

The natural frame is a basic element in the shaping of tourist destinations, having multiple functions, including the material support of all activities including tourism, esthetical features (landscape) and last but not least, the relief it is a tourism resource itself (Herman and Tătar, 2015; Herman and Wendt, 2011; Herman et al., 2017; Ilie et al., 2017). In this context, the analysis of the natural environment as a factor of motivation highlights the followings: the karst relief with the two networks of caves, some of them planned for tourism (Meziad Cave, Crystal Cave from Farcu Mine, Ungurul Mare Cave and Vadu Crişului Cave), other caves are not planned for tourism but they offer speoturism opportunities (Wind Cave, Bătrânului, Ciur-Ponor, Craiului, Doboş, Gălăşeni, Gruieţului, Hârtopul Bonchii, Moanei and Osoi). It also has to be mentioned the karst plateaus (from Runcuri, Zece Hotare and Damiş-Ponoraş), the gorges (Videi, Cuților, Lazurilor, Sohodol, Albioarei, Mişidului, Brătcuţei), the waterfalls (Cailor Waterfall, on the Boiului Valley and Vadu Crişului Waterfall, on the Crişul Repede Valley).

Strongly related to the characteristics of the natural frame and viewed from the perspective of physical life support for the local communities, a series of anthropic attractions have to be mentioned, such as the wooden churches, historical monuments (from the villages of Beznea, Valea Crisului, Josani, Hotar, Vârciorog, Fasca, and Petreasa, Gurbeşti, Goila, Câmpani de Pomezeu, Vălani de Pomezău etc), the historical stone church from Vadu Crișului, the Roșia water mill, the workshops for pottery in Vadu Crișului and for egg painting in Drăgoteni, the horn violin from Lazuri de Roșia (figure 1).

It is clear from the previous analyses, that the natural and anthropic tourism potential of the Pădurea Craiului Mountains (through its features like the low altitudes, the accessibility, the presence of the karst relief, the traditional villages) is significant. This mountain area belongs to the most favorable category for the emergence and development of all forms and types of tourism. Among them, considering older times and the number of participants, we mention speoturism, climbing and mountain hiking, and of relatively recent times, rafting, via-ferrata, cyclotourism and tyrolean.

\section{CONCLUSIONS}

Pădurea Craiului Mountains have a remarkable potential for sport and adventure tourism, this could be turning them in a top destination. Efforts that have been made over the last decade in this direction are becoming visible. Unfortunately, there is no integrated tourism development strategy for the whole area, therefore the local individual actions do not reach the maximum level of capitalization. There are deficiencies in the tourism and communication infrastructure, as well as in the needed facilities for tourism orientation and information. However, there is a positive evolution, as the number of operators in the Pădurea Craiului Mountains is increasing. In tourism development it is desirable to consider the principle of sustainable development in the overall planning of the mountain area, taking into account the valuable and fragile natural and cultural heritage. The recreational tourism in all its forms is very well integrated into this concept. A concrete example is the touristic capitalization of the ten speoturistic caves, they are opened to the 
public under a controlled access, the planning of the caves is limited to minimal elements just to ensure access. In terms of mountaineering, in recent years we can notice the valorization of the old trails by re-equipping them according to the escalade and climbing standards. In parallel, new climbing areas were created doubling this way the existing tourist offer, for example in the Osoi area (on the wall close to the homonymous Cave from Vârciorog) and Lazuri Gorges (from Roşia commune). Further, the lack of bike routes, or their overlapping with the sectors of intensely circulated public roads may jeopardize the safety of tourists, being a downside part to this form of tourism, although the potential is very high. Finally, the water sports have an upward trend, especially rafting, which is the most popular sport in the area. In 2018, rafting held $44.91 \%$ of the total number of activities offered by the local tourism operators.

\section{REFERENCES}

Agenţia de Management al Destinaţiei Bihor (2017). Discover Bihor. Experiențe de poveste. Pădurea Craiului. http://travelbihor.ro/wp-content/uploads/2017/10/Padurea-Craiului-RO-RD-Final.pdf

Ballantyne, M., \& Pickering, C. M. (2013). Tourism and recreation: a common threat to IUCN red-listed vascular plants in Europe. Biodiversity and Conservation, 22(13-14), 3027-3044.

Bar, R., Tătar, C. F., \& Herman, G. V. (2016). Satisfaction degree rating of tourist services in Buziaș spa, Timiș County, Romania. GeoJournal of Tourism and Geosites, 18(2): 212-223.

Gaceu, O., \& Herman, G. V. (2010). The climatic and tourist potential of the resort Stana de Vale in the summer season expressed through Burnet, Poulter And Hughes indices. Analele Universităţii din Oradea, Seria Geografie, 20(2), 191-196.

Gaceu, O., Ilieș., M, Păiușan, F., Ilieș, A., Baias, S., Ilieș, D. C., Herman, G. V., Meșter, C., Olah, I., Caciora, T., \& Taut, C. (2018). Methodological issues concerning the preparation of tourism climate studies. GLOREP 2108 Conference, Timisoara 15-17 November, 2018, Conference Proceeding, pp. 71-73.

Gómez-Vega, M., \& Picazo-Tadeo, A. J. (2019). Ranking world tourist destinations with a composite indicator of competitiveness: To weigh or not to weigh?. Tourism Management, 72, 281-291.

Herman G. V. (2009). Omul şi modificările antropice din Câmpia Someşului [The man and anthropogenic changes in Somes Plain], Editura Universităţii din Oradea, 227 pag., ISBN 978-973-759-981-0, Oradea.

Herman, G. V. (2010). Using Geographical Information (GIS) System for Management of Flood Risks in the Somes Plain. In Cross-Border Partnership with Special Regard to the Hungarian - Romanian - Ukrainian Tripartite Border, Book Editors Ioan Horga, Istvan Suli Zakar, Publishing House University of Debrecen Press, p. 175 -179.

Herman, G. V., \& Tătar, C. (2015). Trends and prospects in the evolution and dynamics of the Felix - 1 Mai Spas Tourist System. Analele Universităţii din Oradea, Seria Geografie, 24(1): 116-126.

Herman, G. V., \& Wendt, J. (2011). Development and Promotion of Tourism, an Extra Chance in Maintaining and Asserting the Identity and Specificity of Oaş Land. GeoJournal of Tourism and Geosites, 7(1): 87-94.

Herman, G. V., Deac, A. L., Ciobotaru, A. M., Andronache, I. C., Loghin, V., \& Ilie, A. M. (2017). The role of tourism in local economy development. Bihor County case study. Urbanism. Architecture. Constructions/Urbanism. Arhitectura. Constructii, 8(3), 265-274.

Herman, G. V., Ilieș, D. C., Baias, Ș., Măduța, M. F., Ilieș, A., Wendt, J., \& Josan, I. (2016a). The tourist map, scientific tool that supports the exploration of protected areas, Bihor County, Romania. GeoSport for Society, 4(1), 24-32.

Herman, G. V., Ilieș, D. C., Măduța, M. F., Ilieș, A., Gozner, M., Buhaș, R., \& Mihók-Géczi, I-M-T. (2016b). Approaches regarding the importance of Natura 2000 sites' settings pupil's education through geography. Case study:Valea Rose (Red Valley) Natura 2000, Bihor country, Romania. Journal of Geography, Politics and Society, 6(4), 57-62.

Herman, G. V., Peptenatu, D., Grama, V., \& Pintilii, R. D. (2018). Tourism and Local Development. Study Case: Băile Felix-Băile 1 Mai Tourism System, Bihor County, Romania. Analele Universitatii din Oradea, Seria Geografie, 28(1): 131-137.

Ilie, A. M., Herman, G. V., Ciobotaru, A. M., Grecu, A., Radu, R. A., Visan, M. C., \& Giurgia, M. (2017). The Role of Tourism in Structural Dynamics of the Economic Profile of Sighisoara City. Urbanism. Architecture. Constructions/Urbanism. Arhitectura. Constructii, 8(4), 377-386.

Ilies A., (coordonator); Baias, S., Baias, I., Blaga, L., Buhaș, S., Chiriac, A., Ciocan, J., Dăncuș, M., Deac, A., Dragoș, P., Dumitrescu, G., Gaceu, O., Godea, I., Gozner, M., Grama, V., Herman, G.V., Hodor, N., Hurley, P., Ilieș, D., Ilieș, G., Ilieș, M., Josan, I., Leșe, G., Măduța, F., Mojolic, D., Morar, C., Olaru, M., Stașac, M., Stupariu, M., Sturza, A., Ștefănescu, B., Tătar, C., Vârnav, R., Vlaicu, M., Wendt, J. (2014). Crisana-Maramures. Atlas geografic al patrimoniului turistic/ Geographical atlas of tourism heritage, 302 p (română/engleză); Editura Universității din Oradea, ISBN 978-606-10-1298-5.

Ilieș, A., Wendt, J. A., Ilieș, D. C., Herman, G. V., Ilieș, M., \& Deac, A. L. (2016). The patrimony of wooden churches, built between 1531 and 2015, in the Land of Maramureș, Romania. Journal of Maps, 12(sup1), 597-602.

Ilieș, D. C., Baias, S., Buhaș, R., Ilieș, A., Herman, G. V., Gaceu, O., \& Măduța, F. (2017). Environmental education in protected areas. Case study from Bihor County, Romania. GeoJournal of Tourism and Geosites, 19(1), 126-132.

Ilieș, D. C., Buhaș, R., Ilieș, A., Morar, C., \& Herman, G.V. (2015). Nymphaea Lotus Var. Thermalis (Pârâul Pețea Nature 
Reserve), Brand Near Extinction of the Băile Felix - Băile 1 Mai (Romania) Spa Tourism System. GeoJournal of Tourism and Geosites, 15(1): 107-117.

Ilieș, D. C., Herman, G., Ilieș, A., Baias, Ș., Dehoorne, O., Buhaș, S., \& Ungureanu, M. (2017). Tourism and Biodiversity in Natura 2000 Sites. Case Study: Natura 2000 Valea Roșie (Red Valley) Site, Bihor County, Romania. Études caribéennes, (37-38).

Ilieş, D., Blaga, L., Josan, I., Baias, Ş., Morar, C., \& Herman, G. (2010). Cross-border natural Parks, support for regional development. Case study of the northern and western Romanian border. Revista Romană de Geografie Politică, 12(1), 126-139.

Kapera, I. (2018). Sustainable tourism development efforts by local governments in Poland. Sustainable cities and society, 40, 581-588.

Lindner-Cendrowska, K. (2013). Assessment of bioclimatic conditions in cities for tourism and recreational purposes (a Warsaw case study). Geographia Polonica, 86(1), 55-66.

Mariani, M. M., Buhalis, D., Longhi, C., \& Vitouladiti, O. (2014). Managing change in tourism destinations: Key issues and current trends. Journal of Destination Marketing \& Management, 2(4), 269-272.

Matoga, Ł., \& Pawłowska, A. (2018). Off-the-beaten-track tourism: a new trend in the tourism development in historical European cities. A case study of the city of Krakow, Poland. Current Issues in Tourism, 21(14), 1644-1669.

Mendola, D., \& Volo, S. (2017). Building composite indicators in tourism studies: Measurements and applications in tourism destination competitiveness. Tourism Management, 59, 541-553.

Morar C. (2011). Several Social Impacts of Mine Closures in the Disadvantaged Areas of Bihor County, Romania. Forum Geographic, 10(2): 303-311.

Morar C. (2012a). Demographic Characteristics of the Disadvantaged Mining Areas in Bihor Areas in the Bihor County, Romania. Analele Universitătii din Oradea, Seria Geografie, 22 (1): 163-174.

Morar C. (2012b). Tourism Development Based on European and National Funding Programs in the Bihor County's Disadvanateged Mining Areas. Revista Română de geografie Politică, 14(1): 99-108.

Novac, I. (2006). Munții Pădurea Craiului (Pădurea Craiului Mountains), Editura Tipo MC, Oradea (in Romanian).

Rankin, B. L., Ballantyne, M., \& Pickering, C. M. (2015). Tourism and recreation listed as a threat for a wide diversity of vascular plants: a continental scale review. Journal of environmental management, 154, 293-298.

Romocea, T., Oneț, A., Sabău, N.C., Oneț, C., Herman, G.V., \& Pantea, E. (2018). Change of the groundwater quality from industrial area Oradea, Romania, using Geographic Information Systems (GIS). Environmental Engineering \& Management Journal (EEMJ), 17(9): 2189-2199.

Rosik, P., Komornicki, T., \& Goliszek, S. (2018). Traffic Modeling in Poland at the Municipal Level. Multi-purpose Model. In Scientific And Technical Conference Transport Systems Theory And Practice (pp. 129-140). Springer, Cham.

Rusu, T. (1988). Carstul din Munţii Pădurea Craiului, Editura Dacia, Cluj-Napoca (in Romanian).

Sainaghi, R., Phillips, P., \& Zavarrone, E. (2017). Performance measurement in tourism firms: A content analytical metaapproach. Tourism Management, 59, 36-56.

Siikamäki, P., Kangas, K., Paasivaara, A., \& Schroderus, S. (2015). Biodiversity attracts visitors to national parks. Biodiversity and conservation, 24(10), 2521-2534.

Tătar, C. F., Herman, G. V., Dehoorne, O., \& Zarrilli, L. (2017). Ecotourism in the Danube Delta. Analele Universităţii din Oradea, Seria Geografie, 27(1): 122-132.

Tolvanen, A., \& Kangas, K. (2016). Tourism, biodiversity and protected areas-review from northern Fennoscandia. Journal of environmental management, 169, 58-66.

Toral, S. L., Martínez-Torres, M. R., \& Gonzalez-Rodriguez, M. R. (2018). Identification of the Unique Attributes of Tourist Destinations from Online Reviews. Journal of Travel Research, 57(7), 908-919.

Wendt, J., Buhaș, R., \& Herman, G. V. (2019). Experience of the Baile-Felix Tourist System (Romania) For the Protection and Promotion of the Grey Seal as a Brend on the Hel Peninsular (Poland). Baltic Region/Baltijskij Region, 11(1): 109-116.

Więckowski, M., Michniak, D., Bednarek-Szczepańska, M., Chrenka, B., Ira, V., Komornicki, T., \& Świątek, D. (2014). Road accessibility to tourist destinations of the Polish-Slovak borderland: 2010-2030 prediction and planning. Geographia Polonica, 87(1), 5-26.

*** (1987). Geografia României vol.III, Editura Academiei R.S.R, Bucureşti.

*** (1983). Geografia României vol.I, Editura Academiei R.S.R, Bucureşti

*** (2018). Lista structurilor de primire turistică cu funcţiuni de alimențaţie publică (LSPTAP), http://www.mdrt.ro/turism/unitati-clasificate

*** (2018). Lista structurilor de primire turistică cu funcţiuni de cazare (LSPTC), http://www.mdrt.ro/turism/unitati-clasificate https://www.padureacraiului.ro/speoturism

http://www.salvamontbihor.ro/page/trasee-turistice

http://alpinismbihor.ro

http://alpinismbihor.ro

http://salvamontbihor.ro/page/via-ferrata-vad

https://padureacraiului.ro/rent-a-bike

https://padureacrai

Submitted:

April 27, 2019
Revised:

May 15, 2019
Accepted and published online June 28, 2019 